\title{
Upaya Meningkatkan Kepercayaan Diri Melalui Bimbingan Konseling Kelompok Pada Siswa Kelas X IPS 1 SMA Negeri 1 Weleri Semester 1 Tahun Pelajaran 2017/2018
}

\author{
Yetty Handayani \\ Guru SMA Negeri 1 Weleri
}

SMA Negeri 1 Weleri

Guru SMA Negeri 1 Weleri

\begin{abstract}
Abstrak
Tujuan penelitian: mengetahui proses peningkatan kepercayaan diri, besarnya peningkatan, perubahan perilaku setelah bimbingan konseling kelompok.Penelitian tindakan bimbingan kelas terdiri dua siklus, tiap siklus terdiri 3 pertemuan: perencanaan, tindakan, observasi dan refleksi. siswa dengan rasa percaya diri sangat rendah, tidak bersemangat, tidak ada motivasi, pada siklus I menunjukan perubahan: dinamis, semangat dan termotivasi. Siklus 2 sangat dinamis, percaya diri, penuh semangat, sangat termotivasi penuh optimis dalam hidup.

Katakunci: kepercayaan diri, layanan bimbingan kelompok

Abstract : The purposes of research: to know the process of improving self-confidence, the magnitude of improvement, behavior change after group counseling guidance. Classroom counseling research consists of two cycles, each cycle there are 4 stages : planning, action, observation and reflection. Students with low self-esteem, lack of enthusiasm, no motivation. Cycle I shows changes: dynamic, passionate and motivated. Cycle II is very dynamic, confident, full of spirit, highly motivated full of optimism in life, increase confidence. Changes in student behavior are more positive: polite and friendly.
\end{abstract}




\section{PENDAHULUAN}

Siswa adalah individu yang sedang mengalami masa perkembangan, yaitu berkembang kearah kematangan atau kemandirian. Pada masa ini siswa membutuhkan banyak bimbingan untuk memperluas pengetahuan dan wawasan tentang dirinya dan lingkungannya. Siswa sebagai makhluk sosial hidup berada di lingkungan yang menjadi tempat untuk bergaul, baik di lingkungan rumah, di sekolah, dan masyarakat, oleh karena itu siswa perlu memiliki kepercayaan diri yang dapat menunjang penerimaan lingkungan terhadapnya.

Kepercayaan diri atau Self Confidence adalah sejauhmana individu punya keyakinan terhadap penilaiannya atas kemampuan dirinya dan sejauhmana individu bisa merasakan adanya kepantasan untuk berhasil (Neil, 2005). Kepercayaan diri membuat siswa merasa nyaman berada di lingkungan tempat individu tersebut berada sehingga siswa merasa yakin terhadap suatu langkah dan keputusan yang diambilnya guna mencapai tujuan yang diharapkannya. Dengan demikian percaya diri merupakan hal yang penting karena dalam sikap percaya kita dapat memiliki kekuatan dan kemampuan yang dimiliki serta kepuasan terhadap diri yang bersifat batiniah maupun jasmaniah yang mampu mampu mengendalikannya dalam mencapai tujuan yang diharapkannya. Jadi orang yang percaya diri memiliki rasa optimis dengan kelebihan yang dimiliki dalam mencapai tujuan yang telah ditetapkan. Siswa yang mempunyai rasa percaya diri tinggi dapat memahami kelebihan dan kelemahan yang dimiliki. Kelemahan- kelemahan yang ada pada dirinya merupakan hal yang wajar dan sebagai motivasi untuk mengembangkan kelebihan yang dimilikinya bukan dijadikan penghambat atau penghalang dalam mencapai tujuan yang telah ditetapkan.

Menurut Surya (2007:2) menyatakan bahwa kepercayaan diri yang melekat pada diri individu bukan bawaan sejak lahir atau keturunan melainkan hasil proses belajar bagaimana merespon berbagai rangsangan dari luar melalui interaksi dengan lingkungannya. Kita sering merespon berbagai rangsangan atau fenomena dari luar kemudian kita mempersepsikannya. Bila kita mempersepsikan secara negatif dalam melakukan sesuatu, maka yang ditimbulkan adalah perasaan yang tidak menyenangkan kemudian timbul perasaan untuk menghindarinya.

Menurut Santrock (2003: 338) menyebutkan bahwa ada dua sumber dukungan sosial yang berpengaruh terhadap rasa percaya diri yaitu hubungan dengan orang tua dan teman sebaya. Hubungan kasih sayang, perhatian, suasana yang harmonis, dan pemberian kebebasan pada anak untuk berekpresi dalam batas-batas yang telah ditentukan akan membangun kepercayaan diri pada individu. Hubungan dengan teman sebaya dapat berwujud dukungan terhadap suatu hal yang dilakukan individu tersebut. Individu yang mempunyai aktivitas sosial akan membuat wawasan sosialnya semakin baik. jadi semakin seseorang terlibat banyak dalam berbagai aktifitas sosial maka kompetensi sosial dan kepercayaan diri remaja juga akan semakin meningkat.

Percaya diri juga lahir dari kesadaran, kesadaran akan memutuskan yang menjadikan suatu tekad yang kuat untuk melakukan segala sesuatu. Misalnya saya ingin mendapat nilai ujian yang bagus,maka saya akan berusaha secara maksimal sampai tujuan saya tercapai dengan cara belajar yang lebih giat. Hakim (2005:2) menjelaskan terbentuknya rasa percaya diri yang kuat terjadi melalui proses antara lain terbentuknya kepribadian yang baik sesuai dengan proses perkembangan yang melahirkan kelebihankelebihan tertentu, pemahaman seseorang terhadap kelebihan-kelebihan yang dimilikinya dan melahirkannya keyakinan yang kuat untuk bisa berbuat segala sesuatu dengan memanfaatkan kelebihankelebihannya, pemahaman dan reaksi positif seseorang terhadap kelemahan- kelemahan yang dimilikinya agar tidak menimbulkan rasa rendah diri, pengalaman di dalam menjalani berbagai aspek kehidupan dengan menggunakan segala kelebihan yang ada pada dirinya.

Seseorang yang memiliki percaya diri tinggi juga dapat dilihat dari ciri ciri tertentu. Menurut Hakim (2005:5) ciri-ciri orang yang mempunyai kepercayaan diri tinggi antara lain, selalu bersikap tenang didalam mengerjakan segala sesuatu, mempunyai potensi dan kemampuan yang memadai, mampu menetralisasi ketegangan yang muncul didalam berbagai situasi, mampu menyesuaikan diri dan berkomunikasi di berbagai situasi, memiliki kondisi mental dan fisik yang cukup menunjang penampilannya, memiliki kecerdasan yang cukup, memiliki tingkat pendidikan formal yang cukup, 
memiliki keahlian atau ketrampilan lain yang menunjang kehidupannya, misalnya ketrampilan berbahasa asing, memilikikemampuan bersosialisasi memiliki latar belakangpendidikan yang baik, memiliki pengalaman hidup yang menempa mentalnya menjadi kuat dan tahan didalam menghadapi berbagai cobaan hidup, selalu bereaksi positif didalam menghadapi berbagai masalah. Hal ini merupakan modal utama bagi seseorang untuk mewujudkan dan mengembangkan potensi dirinya untuk mencapai yang terbaik dengan tujuan kehidupannya.

Seorang yang tidak memiliki percaya diri juga dapat dilihat dari ciri-ciri tertentu. Manutur Hakim (2005) menyatakan bahwa indikator perilaku negatif individu yang tidak percaya diri. Mudah cemas, gugup, tdak tahu cara mengembangkan diri, menyendiri, mudah putus asa, bergantung pada orang lain, menghindari masalah.dapat dismpulkan bahwa anak yang ragu terhadap kemampuan diri sendiri biasanya kurang dapat menyampaikan pesan kepada orang lain karena salah satu faktor penyebab tidak percaya diri datang dari kemampuan berkomunikasi secara verbal dengan berbicara. Dengan demikian perlua adanya cara untuk mengembangkan kepercayaan diri. Menurut Ananda (2010) menyatakan bahwa ada beberapa cara yang dapat mengembangkan kepercayaan diri antara laian selalu berfikir positif, memilih teman yang positif, jangan menunda-nunda tindakan, sikapilah gagal dengan bijaksana. Hal tersebut dapat mengembangkan rasa percaya dapat dapat berdampak tegas dalam menentukan pilihan, semangat yang positif, menghilangkan rasa takut, mehat secara fisik dan mental serta memperbesar peluang meraih citacita.

Pentingnya memiliki kepercayaan diri dalam proses belajar di kelas supaya siswa dapat mengaktualisasikan diri. Sehingga siswa dapat menemukan dan mengembangkan potensi yang dimiliki. Kepercayaan diri merupakan aspek yang sangat penting bagi sesorang untuk dapat mengembangkan potensinya.Jika seseorang memiliki bekal kepercayaan diri yang baik, maka individu tersebut akan dapat mengembangkan potensinya dengan mantap. Namun jika seseorang memiliki kepercayaan diri rendah, maka individu tersebut cenderung menutup diri, mudah frustasi ketika menghadapi kesulitan, canggung dalam menghadapi orang, dan sulit menerima realita dirinya.

Kepercayaan diri saat maju di depan kelas, dapat meningkatkan keberanian siswa dalam menjawab pertanyaan.Kepercayaan diri dapat meningkatkan komunikasi dengan baik, memiliki ketegasan, mempuyai penampilan diri yang baik, dan mampu mengendalikan perasaan. Memiliki kepercayaan diri yang tinggi dalam diri siswa dapat membantu mencapai prestasi dan hasil belajar yang lebih baik lagi. Anak yang ragu terhadap kemampuan diri sendiri / tidak percaya diri biasanya kurang dapat berbicara atau menyampaikan pesan kepada orang lain. Dengan begitu akan terjadi proses perubahan dalam diri siswa bukan hanya pada hasil belajar tetapi juga pada perilaku dan sikap siswa, yaitu keberanian, keaktifan, dan aktualisasi diri siswa saat proses belajar mengajar.

Pada kenyataan di lapangan, kondisi kepercayaan diri siswa berbeda- beda, sementara disisi lain siswa butuh komunikasi secara verbal. Hal ini dapat dilihat dari adanya gejala-gejala yang tampak diantaranya ragu-ragu saat berbicara di depan kelas dan diam saat ditunjuk guru untuk maju di depan kelas, adapun gejala yang lain seperti takut untuk menyampaikan pendapat atau tanggapan saat berdiskusi kelompok. Pada diskusi kelompok mereka cenderung diam dan pasif.

Guru adalah pendidik professional dengan tugas utama mendidik, mengajar, membimbing, mengarahkan, melatih, menilai, dan mengevaluasi peserta didik pada pendidikan anak usia dini jalur pendidikan formal, pendidikan dasar, dan pendidikan menengah. Mendidik berarti meneruskan dan mengembangkan nilai-nilai hidup. Mengajar berarti meneruskan dan mengembangkan ilmu pengetahuan dan teknologi. Sedangkan melatih berarti mengembangkan ketrampilan-ketrampilan kepada siswa.Bimbingan dan konseling merupakan salah satu komponen penting dalam dunia pendidikan. Diadakannya layanan bimbingan dan konseling di sekolah bukan karena adanya landasan hukum, namun yang lebih penting adalah adanya kesadaran atau komitmen untuk memfasilitasi siswa agar mempunyai kepercayaan diri sehingga dapat mengembangkan potensi dirinya.

BP/BK (Bimbingan Penyuluhan / Konseling) sebagai salah satu bagian di lembaga pendidikan formal merupakan wahana untuk meningkatkan ketrampilan, sikap, dan nilai.Pendidikan yang di terapkan oleh BP/BK (Bimbingan Penyuluhan / Konseling) menekankan pada pemberian pengalaman secara langsung.Tujuan pendidikan BP/BK (Bimbingan Penyuluhan / Konseling) adalah membantu siswa 
memahami ketrampilan, sikap, dan nilai.dan saling keterkaitannya, mengembangkan ketrampilan dasar untuk menumbuhkan nilai serta sikap ilmiah, menerapkan konsep dan prinsip untuk menghasilkan karya ketrampilan, sikap, dan nilai yang berkaitan dengan kebutuhan manusia. Maka metode yang digunakan dalam pembelajaran BP/BK (Bimbingan Penyuluhan / Konseling) harus merupakan metode yang mengandung esensi pendekatan-pendekatan yang digunakan dalam pengetahuan ilmiah untuk meningkatkan kepercayaandiri siswa. Menurut Prayitno (2004: 65) proses kegiatan bimbingan kelompok terdiri atas beberapa tahap, antara lain: 1) tahap Pembentukan 2) tahap Peralihan 3) tahap Kegiatan 4) tahap Pengakhiran.

Bimbingan dan Konselingharus bisa menjalankan profesinya yaitu mengonseling siswa yang bermasalah / atau butuh pemecahan masalah. Dengan menggunakan layanan bimbingan kelompok akan dapat membantu masalah siswa berkaitan dengan kepercayaan dirinya yang kurang. Karena di dalam bimbingan kelompok memfasilitasi siswa untuk bertukar pendapat, Dengan menggunakan layanan bimbingan kelompok menolong individu untuk dapat memahami bahwa oranglain ternyata mempunyaikebutuhandan masalah yang sama berhubungan dengan aspek kepercayaan dirisiswadalamproses pembelajaran. Melaluibimbingan kelompok ini dimungkinkan akan dapat membantu masalah siswa berkaitan dengan kepercayaan dirinya. Karena didalam bimbingan kelompok akan memfasilitasi siswa untuk bertukar pendapat, lebih mudah untuk menangkap persoalan yang dihadapinya dan cara mengatasinya.

Teknik yang digunakan dalam bimbingan kelompok ini adalah teknik dinamika kelompok yang mengacu pada perkembangan dinamika kelompok yang diikuti oelh seluruh anggota kelompok, dalam rangka mencapai tujuan layanan. Dalam pelaksanaan proses konseling, guru seringkali dihadapkan dengan berbagai macam masalah, terutama masalah-masalah yang terkait dengan keberhasilan proses konseling. Keberhasilan dalam konseling terlihat dari siswa yang menemukan solusi atas masalahnya. Keberhasilan siswa dalam menyelesaikan masalahnya tidak terlepas dari peran aktif guru BK, begitu juga dengan keberhasilan siswa dari segi emosional. Hal ini pun di tentukan oleh guru, khususnya guru BP/BK yang mampu memberi motivasi dan dapat menciptakan iklim / suasana yang harmonis, kondusif, menyenangkan dan mampu memberi semangat kepada siswa.

Berdasarkan fenomena tersebut maka peneliti tertarik untuk membantu siswa meningkatkan kepercayaan diri dengan menggunakan bimbingan kelompok. Oleh karena itu, penulis merasa tertarik untuk melakukan penelitian lebih mendalam dengan judul "Upaya Meningkatkan Kepercayaan Diri melalui bimbingan KelompokPada Siswa Kelas X IPS 1 SMANegeri 1 Weleri Semester 1 Tahun Pelajaran 2017/ 2018". Tujuan Penlitian ini Mengetahui proses peningkatan kepercayaan diri siswa Kelas X IPS 1 SMANegeri 1 Weleri Semester 1 Tahun Pelajaran 2017/ 2018 melalui bimbingan konseling kelompok melalui bimbingan kelompok. Mengetahui besarnya peningkatan kepercayaan diri siswa Kelas X IPS 1 SMANegeri 1 Weleri melalui bimbingan kelompok. Mengetahui perubahan perilaku siswaKelas X IPS 1 pada SMANegeri 1 Weleri melalui bimbingan kelompok

\section{METODE}

Jenis penelitian yang digunakan pada penelitian ini adalah penelitian tindakan atau Penelitian Tindakan Bimbingan dan Konseling (PTBK). Analisis pada Penelitian Tindakan Bimbingan Konseling yang dilakukan secara kuantitatif karena Penelitian Tindakan Bimbingan Konseling bisa menggunakan tindak lanjut dari penelitian eksperimen maupun penelitian deskriptif presentase untuk mengetahui nilai yang diperoleh pada peserta didik. Menurut Hidayat dan Badrujaman (2012), "guru Bimbingan dan Konseling dapat melakukan penelitian berupa penelitian tindakan dalam Bimbingan dan Konseling yang berakronim PTBK. Dalam penelitian ini peneliti dapat langsung mencoba dan menerapkannya layanan bimbingan Kelompok dengan Teknik dinamilka kelompok untuk Meningkatkan percaya diri pada peserta didik. Pelaksanaan Siklus I diawali a)Kegiatan awal, b) Kegiatan inti yang terdiri dari : 1) tahap pembentukan, kelompok. 2) Tahap peralihan. 3) Tahap kegiatan. c) Tahap pengakhiran. Teknik Pengambilan data yang digunakan adalah sebagai berikut : a) Teknik wawancara untuk mengumpulkan data tentang rasa percaya pada kondisi awal. b)Teknik observasi/pengamatan untuk mengumpulkan data tentang rasa percaya. 
Prosedur Penelitian menggunakan dua siklus, tiap siklus Penelitian tindakan ini direncanakan terdiri dari dua siklus yaitu siklus I dan siklus II, akan tetapi jika dalam siklus II pengentasan konflik interpersonal peserta didik belum sesuai dengan target yang ditentukan, dapat dimungkinkan penelitian dilanjutkan ke siklus selanjutnya (siklus semu) terdiri dari empat tahap, yaitu: "1. perencanaan, 2. pelaksanaan tindakan, 3. observasi, dan 4. refleksi" (Suharsimi, 2014). Setelah dilakukan penelitian , maka target yang ingin dicapai / diharapkan adalah sebagai berikut: a) Pada kondisi awal kepercayaan diri rendah, diharapkan pada kondisi akhir meningkat. b) Pada kondisi awal siswa tidak tertarik untuk melakukan bimbingan dengan guru BK, setelah dilakukan penelitian ini siswa menjadi tertarik untuk melakukan bimbingan konseling.

\section{HASIL PENELITIAN DAN PEMBAHASAN}

\section{Hasil Penelitian}

Kondisi Awal sebelum dilaksanakan penelitian tindakan kelas bimbingan dan konseling peneliti melakukan proses pembimbingan awal kepada siswa kelas X IPS1 SMAN 1 Weleri tahun pelajaran $2017 / 2018$, terbukti dengan masih sangat sedikit siswa yang berani tampil di depan kelas, tidak berani mengemukakan pendapat, tidak menghargai pendapat teman, tidak menyadari dengan kemampuan yang dimiliki, tidak bisa menerima kelebihan yang dimiliki teman, tidak bisa menerima kekurangan diri sendiri sehingga anak merasa frustasi. Dari data pembimbingan awal siswa yang antusias menghadapi hidup hanya tujuh anak, mau berbicara dengan percaya diri hanya dua anak, hanya dua siswa yang berani mengungkapkan cita - cita di masa depan, ada anak yang tidak perduli dengan pendapat teman, ada beberapa anak yang tidak semangat di kelas, serta masih ada anak yang belum dapat menunjukkan kelebihannya. Hasil tes kepercayaan diri pada kondisi awal dapat dilihat pada Tabel 1dan Gambar 1 diagram batang berikut:

Tabel 1

Hasil Tes kepercayaan diri pada Kondisi Awal

\begin{tabular}{lllc}
\hline No. & Rentang Skor & F & Kriteria \\
\hline 1 & $85 \%-100 \%$ & 3 & Sangat tinggi \\
2 & $70 \%-84 \%$ & 7 & Tinggi \\
3 & $55 \%-69 \%$ & 5 & Sedang \\
4 & $40 \%-54 \%$ & 5 & Rendah \\
5 & $25 \%-39 \%$ & 8 & Sangat Rendah \\
\hline
\end{tabular}

Hasil test awal kepercayaan diri dapat dilihat dalam grafik sebagai berikut:

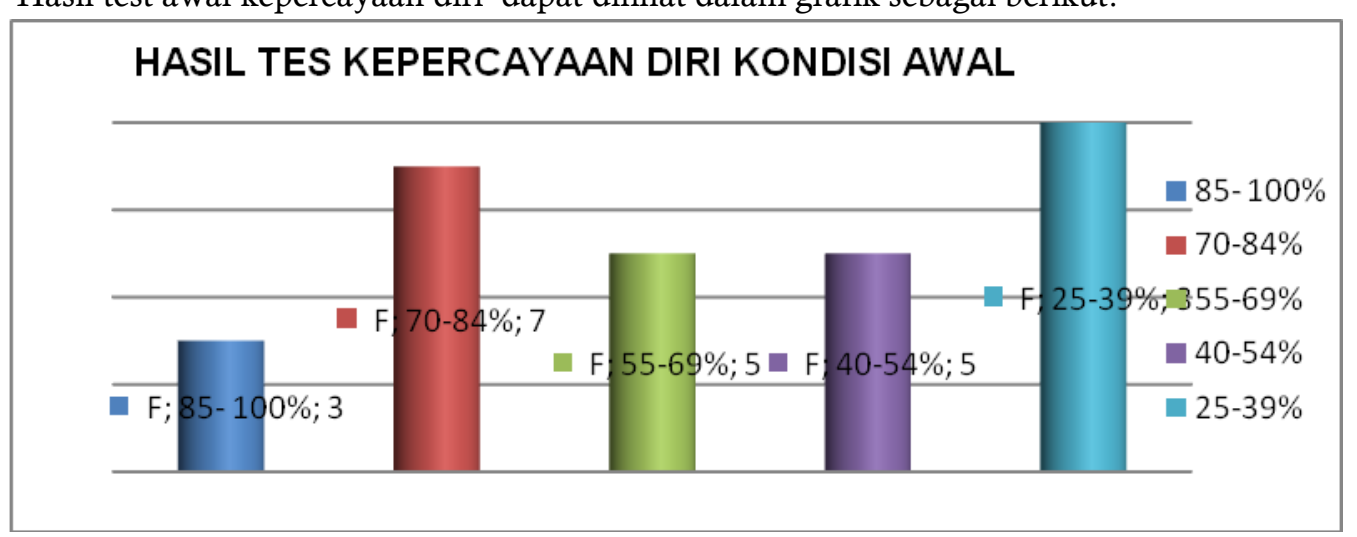

Grafik 1.

Hasil Tes Kepercayaan Diri Kondisi Awal

Dari Grafik1 memperlihatkan kepercayaan diri pada siswa kelas X IPS 1 SMAN 1 Weleri semester 1 tahun $2017-2018$ terlihat terdapat 8 siswa dengan kondisi kepercayaan diri yang sangat rendah, hanya 3 
siswa yang mempunyai rasa percaya diri sangat tinggi,7siswa mempunyai rasa percaya diri tinggi, 5 dengan rasa percaya diri sedang dan 5 siswa berada pada rasa percaya diri rendah.

Siklus I

Pengamatan hasil tindakan bimbingan kelompok siswa pada siklus I dapat dilihat pada Tabel 2 serta diagram batang 2 berikut ini.

Tabel 2

Hasil Tes kepercayaan diri pada Siklus I

\begin{tabular}{rlcc}
\hline No. & Rentang Skor & F & Kriteria \\
\hline 1 & $85 \%-100 \%$ & 5 & Sangat tinggi \\
2 & $70 \%-84 \%$ & 10 & Tinggi \\
3 & $55 \%-69 \%$ & 3 & Sedang \\
4 & $40 \%-54 \%$ & 4 & Rendah \\
5 & $25 \%-39 \%$ & 5 & Sangat Rendah
\end{tabular}

Hasil pengumpulan data yang telah dilakukan kepada siswa kelas XIPS 1 SMA N 1 Welerisemester 1 tahun pelajaran 2017/2018 sejumlah 28 siswa, diperoleh hasil siklus I siswa sebanyak 5 siswa, berada pada kategori sangat tinggi (prosentase antara 85\%-100\%), 10 siswa, berada pada kategori tinggi (prosentase antara 70\%-84\%), 3 siswa, berada pada kategori sedang (prosentase antara 55\%-69\%) dan 4 siswa, berada pada kategori rendah (prosentase antara 40\%-54\%) dan 5 siswa berada pada kategori sangat rendah(prosentase antara $25 \%-539 \%$ ).

Hasil test kepercayaan diri siklus I dapat dilihat dalam grafik sebagai berikut:

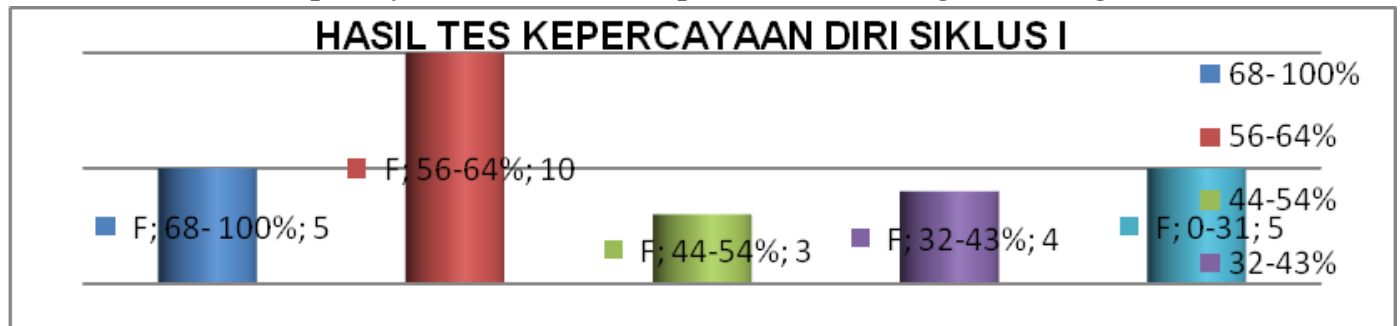

Grafik 2.

Hasil Tes Kepercayaan Diri Siklus I

Dari Grafik 2 memperlihatkan adanya peningkatan rasa kepercayaan diri tetapi masih ada siswa yang masih mempunyai rasa percaya diri yang sangat rendah.

Hasil pengamatan bimbingan kelompok pada siklus I dapat dilihat pada Tabel 3 berikut .

Tabel 3

Hasil pengamatan bimbingan kelompok pada siklus I

\begin{tabular}{clc}
\hline NO & \multicolumn{1}{c}{ Uraian kegiatan } & Siklus I \\
\hline 1 & Semangat & 15 \\
2 & Mau bertanya & 10 \\
3 & Terbuka pada orang lain & 15 \\
4 & Bangga pada diri sendiri & 19 \\
5 & Termotivasi & 17 \\
6 & Mendengarkan orang lain & 15 \\
7 & Memahami perasaan orang lain & 20 \\
\hline
\end{tabular}


Data Bimbingan Konseling Kelompok pada kondisi awal dan siklus I dapat dilihat pada tabel berikut .

Tabel 4

Konseling Kelompok pada kondisi awal dan siklus I

\begin{tabular}{ccccc}
\hline No. & Rentang Skor & Konsisi Awal & Siklus I & Peningkatan \\
\hline 1 & $85 \%-100 \%$ & 3 & 5 & 2 \\
2 & $70 \%-84 \%$ & 7 & 10 & 3 \\
3 & $55 \%-69 \%$ & 5 & 3 & 2 \\
4 & $40 \%-54 \%$ & 5 & 4 & 1 \\
5 & $25 \%-39 \%$ & 8 & 5 & 3 \\
\hline
\end{tabular}

Pada kondisi awal peneliti belum melakukan bimbingan konseling kelompok kepada 28 siswa terdapat delapan siswa yang mempunyai rasa percaya diri sangat rendah, setelah dilakukan bimbingan kenseling kelompok anak yang mempunyai rasa percaya diri sangat rendah berkurang menjadi 5 . Ada peningkatan dari dari $28,6 \%$ menjadi $17,9 \%$.

Perubahan Perilaku setelah siklus I dengan mengambil 15 anak semua siswa merasakan suasana yang lebih menyenangkan. Lima siswa menyatakan lebih mudah bergaul dan menyatakan pendapat, dua siswa menyatakan lebih termotivasi, dua siswa menyatakan lebih percaya diri menghadapi masa depan, empat siswa menyatakan bangga akan kemampuan dan bakat yang dimiliki, dan dua siswa menyatakan lebih termotivasi dan optimis dalam kehidupan.Mengingat belum terpenuhinya target atau indikator yang telah ditetapkan maka penelitian ini akan dilanjutkan pada siklus II

Siklus II

Peneliti melanjutkan dengan melakukan Siklus II , pengamatan hasil tindakan bimbingan kelompok pada siklus II dapat dilihat pada tabel 5 serta diagram batang 3 berikut ini.

Tabel 5

Hasil Tes kepercayaan diri padaSiklus II

\begin{tabular}{llcc}
\hline No. & Rentang Skor & F & Kriteria \\
\hline 1 & $85 \%-100 \%$ & 8 & Sangat tinggi \\
2 & $70 \%-84 \%$ & 12 & Tinggi \\
3 & $55 \%-69 \%$ & 5 & Sedang \\
4 & $40 \%-54 \%$ & 2 & Rendah \\
\hline
\end{tabular}

Hasil pengumpulan data yang telah dilakukan kepada siswa kelas XIPS 1 SMA N 1 Welerisemester 1 tahun pelajaran 2017 - 2018 sejumlah 28 siswa, memperlihatkan hasil bimbingan konseling kelompok Siklus II yang diperoleh siswa, sebanyak 8 siswa (29 \%) meningkat kepercayaan dirinya tetapi masih ada siswa yang mempunyai kepercayaan diri yang rendah sebanyak 2 siswa (7\%).

Hasil test kepercayaan dirisiklus II dapat dilihat dalam grafik sebagai berikut:

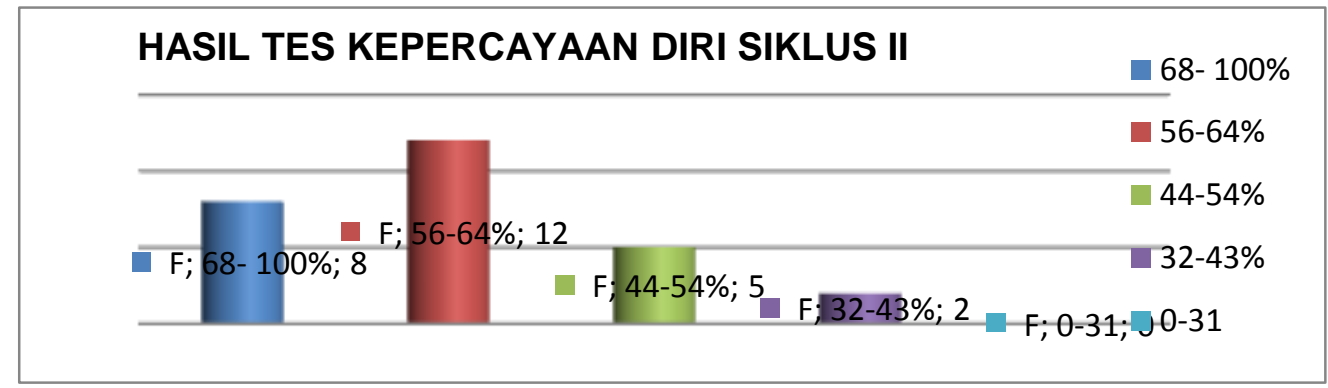


Dari Grafik 3 memperlihatkan adanya peningkatan rasa kepercayaan diri tetapi masih ada siswa yang masih mempunyai rasa percaya diri yang rendah.

Pada pertemuan ke dua pada siklus II ini semua anggota berpartisipasi aktif dalam mengungkapkan pendapatnya, anggota kelompok sudah terlihat nyaman dan saling bercanda satu dengan yang lain. Bimbingan kelompok pada pertemuan ke dua ini berjalan lancar dan menyenangkan.

Hasil pengamatan bimbingan kelompok pada siklus II dapat dilihat pada tabel berikut :

Tabel 6

Hasil pengamatan bimbingan kelompok pada siklus II

\begin{tabular}{clc}
\hline NO & \multicolumn{1}{c}{ Uraian kegiatan } & Siklus II \\
\hline 1 & Semangat & 20 \\
2 & Mau bertanya & 15 \\
3 & Terbuka pada orang lain & 20 \\
4 & Bangga pada diri sendiri & 25 \\
5 & Termotivasi & 20 \\
6 & Mendengarkan orang lain & 25 \\
7 & Memahami perasaan orang lain & 25 \\
\hline
\end{tabular}

Hasil Bimbingan Konseling Kelompok setelah siklus I dan siklus II dapat dilihat pada tabel berikut :

Tabel 7

Hasil Konseling Kelompok pada siklus I dan siklus II

\begin{tabular}{|l|l|c|c|c|}
\hline No. & Rentang Skor & Siklus I & Siklus II & Refleksi \\
\hline 1 & $85 \%-100 \%$ & 5 & 8 & 3 \\
\hline 2 & $70 \%-84 \%$ & 10 & 12 & 2 \\
\hline 3 & $55 \%-69 \%$ & 3 & 5 & 2 \\
\hline 4 & $40 \%-54 \%$ & 4 & 2 & 2 \\
\hline 5 & $25 \%-39 \%$ & 5 & - & - \\
\hline
\end{tabular}

Pada siklus II peneliti telah melakukan bimbingan konseling kelompok kepada 28 siswa terdapat delapan siswa yang mempunyai rasa percaya diri sangat rendah, setelah dilakukan bimbingan kenseling kelompok anak yang mempunyai rasa percaya diri sudah tidak ada lagi. Ada peningkatan dari 17,9\% menjadi $0 \%$.

\section{Pembahasan Hasil Penelitian}

Peningkatan kepercayaan diri pada siswa kela X IPS 1 SMAN 1 Weleri terlihat dari tabel berikut ini :

Tabel 8

Hasil Pengamatan Bimbingan Konseling Kelompok Siklus I, dan Siklus II

\begin{tabular}{|c|l|c|c|}
\hline NO & \multicolumn{1}{|c|}{ Uraian kegiatan } & Siklus I & Siklus II \\
\hline 1 & Semangat & 15 & 20 \\
\hline 2 & Mau bertanya & 10 & 15 \\
\hline 3 & Terbuka pada orang lain & 15 & 20 \\
\hline 4 & Bangga pada diri sendiri & 19 & 25 \\
\hline 5 & Termotivasi & 17 & 20 \\
\hline 6 & Mendengarkan orang lain & 15 & 25 \\
\hline 7 & Memahami perasaan orang lain & 20 & 25 \\
\hline
\end{tabular}

Peningkatan Hasil Bimbingan Konseling Kelompok terlihat pada tabel berikut. 
Tabel 9

Peningkatan Hasil Bimbingan Konseling Kelompok

\begin{tabular}{llcccc}
\hline No & Rentang Skor & $\begin{array}{c}\text { Kondisi } \\
\text { Awal }\end{array}$ & Siklus I & Siklus II & perubahan \\
\hline 1 & $85 \%-100 \%$ & 3 & 5 & 8 & 3 \\
2 & $70 \%-84 \%$ & 7 & 10 & 12 & 2 \\
3 & $55 \%-69 \%$ & 5 & 3 & 5 & 2 \\
4 & $40 \%-54 \%$ & 5 & 4 & 2 & 2 \\
5 & $25 \%-39 \%$ & 8 & 5 & - & 0 \\
\hline
\end{tabular}

Kondisi bimbingan konseling kelompok yang akrab dan penuh kepercayaan pada setiap anggota kelompok membuat para konseli menjadi pribadi yang lebih percaya diri, mereka lebih akrab dan terbuka.

Dari hasil angket menggambarkan bahwa dari 28 siswa, sebanyak 51,6 \% menyatakan sangat tertarik, sangat termotivasi, sangat terinspirasi setelah melakukan bimbinagn konseling kelompok. Adapun sebanyak 35,7 \% siswa menyatakan setuju dengan adanya konseling kelompok dan 10,7 \% menyatakan tidak tahu, tak seorangpun menyatakan tidak setuju dan sangat tidak setuju.

Berdasarkan uraian seperti tersebut diatas dapat dirumuskan: a) Melalui bimbingan konseling kelompok dapat meningkatkan kepercayaan diri siswa kelas X IPS 1 SMAN 1 Weleri pada semester 1 tahun pelajaran 2017/2018 dari kondisi awal kepercayaan diri rendah ke kondisi kepercayaan diri sangat tinggi. b) Melalui bimbingan konseling kelompok dari kondisi awal terdapat 5 ( 17,9\%) siswa dengan kondisi kepercayan diri sangat rendah menjadi tidak ada lagi siswa dengan kondisi kepercayan diri sangat rendah pada kondisi akhir.

\section{SIMPULAN DAN SARAN Simpulan}

Setelah bimbingan konseling kelompok kepada 28 siswa pada kondisi awal terdapat siswa yang mempunyai rasa percaya diri sangat rendah, tidak bersemangat, tidak ada motivasi, setelah dilakukan bimbingan kenseling kelompok pada siklus I siswa menunjukan perubahan, smenjadi dinamis, semangat dan termotivasi. Pada akhir penelitian atau siklus II siswa sudah terlihat sangat dinamis, percaya diri, penuh semangat, sangat termotivasi penuh optimis dalam hidup. Konseling kelompok meningkatkan kepercayaan diri dan kedekatan antara siswa kelas X IPS1 SMA N 1 Weleri semester 1 tahun pelajaran 2017/2018 dengan guru pembimbing. Perubahan perilaku yang positif telah nampak setelah dilakukan bimbingan konseling kelompok, siswa lebih sopan, disiplin, jujur, ramah, bersemangat dan termotivasi.

Saran

Ada beberapa saran yang perlu disampaikan sehubungan dengan penelitian ini yaitu sebagai berikut :1) Kepada teman-teman guru yang mengalami masalah dalam mengatasi siswa yang tidak percaya diri hendaknya melakukan pendekatan pada siswa secara pribadi. 2)Bagi para siswa, untuk akrab dan terbuka pada guru BK, demikian juga Guru Bk hendaknya lebih dekat dengan siswa. 3) Kepada Kepala Sekolah, diharapkan agar dapat memfasilitasi konselor sekolah sehingga dapat melaksanakan kegiatan-kegiatan dalam layanan bimbingan dan konseling terutama layanan bimbingan kelompok untuk mengatasi masalah kepercayaan diri siswa. 4) Untuk perpustakaan supaya selalu menambah bahan bacaan terutama yang berkaitan dengan bimbingan konseling. 


\section{DAFTAR PUSTAKA}

Hakim, T. 2005. Mengatasi Rasa TidakPercaya Diri. Jakarta: Puspa Swara

Hidayat, D R dan Badrujman, Aip. 2012. Penelitian Tindakan Dalam Bimbingan Konseling. Jakarta: PT Indek.

James, Neill. 2005. Jenis - jenis percaya diri. Jakarta : alfabeta

Prayitno \& Amti Erman. 2004.Dasar-Dasar Bimbingan Dan Konseling. Jakarta: Rinekacipta.

Prayitno.2004. Layanan Bimbingan Dan Konseling. Padang: Universitas Negeri Padang.

Santrock, Jhon W. 2003. Adolescensce (Perkembangan Remaja). Jakarta:Erlangga.

Suharsimi, Arikunto. 2014. Penelitian Tindakan Kelas. Jakarta : PT Bumi Aksara.

Surya, H. 2007. Percaya Diri Itu Penting. Jakarta : Gramedia. 